\begin{tabular}{|c|c|}
\hline Title & $\begin{array}{l}\text { A melioration of butylated hydroxytoluene against inorganic mercury induced cytotoxicity and mitochondrial apoptosis } \\
\text { in PC12 cellsvia antioxidant effects }\end{array}$ \\
\hline Author(s) & Hossain, Kaniz Fatima Binte; Hosokawa, Toshiyuki; Saito, Takeshi; Kurasaki, Masaaki \\
\hline Citation & $\begin{array}{l}\text { Food and Chemical Toxicology, 146, } 111819 \\
\text { https://doi.org/10.1016/.fct.2020.111819 }\end{array}$ \\
\hline Issue Date & $2020-12$ \\
\hline Doc URL & http:/hdl .handle.net/2115/83396 \\
\hline Rights & $\begin{array}{l}\text { @ 2020. This manuscript version is made available under the CC-BY-NC-ND } 4.0 \text { license } \\
\text { http://creativecommons.org/icenses/by-nc-nd/4.0/ }\end{array}$ \\
\hline Rights(URL) & https://reativecommons.org/icenses/by-nc-nd/4.0/ \\
\hline Type & article (author version) \\
\hline File Information & Food Chem. Toxicol.v146_R1.pdf \\
\hline
\end{tabular}

Instructions for use 


\section{Amelioration of butylated hydroxytoluene against inorganic mercury induced cytotoxicity and mitochondrial apoptosis in PC12 cells via antioxidant effects}

Kaniz Fatima Binte Hossain ${ }^{\mathrm{a}}$, Toshiyuki Hosokawa ${ }^{\mathrm{b}}$, Takeshi Saito ${ }^{\mathrm{c}}$, Masaaki Kurasaki ${ }^{\mathrm{a}, \mathrm{d}, *}$

${ }^{\mathrm{a}}$ Graduate School of Environmental Science, Hokkaido University, Sapporo 060-0810, Japan

${ }^{\mathrm{b}}$ Institute for the Advancement of Higher Education, Hokkaido University, Sapporo 060-0817, Japan

${ }^{\mathrm{c}}$ Faculty of Health Sciences, Hokkaido University, Sapporo 060-0812, Japan

${ }^{\mathrm{d}}$ Faculty of Environmental Earth Science, Hokkaido University, Sapporo 060-0810, Japan

*:Address correspondence to:

Kaniz Fatima Binte Hossain

Graduate School of Environmental Science, Hokkaido University.

Kita 10 Nishi 5, Kita-ku Sapporo 060-0810 JAPAN

Phone: +81-090-8276-8067, fax: +81-11-706-4864

E-mail: rumana@ees.hokudai.ac.jp 


\section{Abstract}

Mercury $(\mathrm{Hg})$ is a toxic metal, well-known for its dangerous health effects on human. Butylated hydroxytoluene (BHT) is a phenolic component generally consumed as a food additive as an antioxidant. However, BHT induced antioxidant properties against heavy metals-influenced toxicity are little studied. We hypothesized that BHT has a regulatory effect on $\mathrm{Hg}$-induced cytotoxicity. The objective of this research was to assess the protecting effects of BHT against inorganic $\mathrm{Hg}(\mathrm{iHg})$-toxicity in $\mathrm{PC} 12$ cells, where cells were treated with/without $\mathrm{HgCl}_{2}\left(\mathrm{Hg}^{2+}\right)(5 \mu \mathrm{M})$ and BHT $(100 \mu \mathrm{M})$ for $48 \mathrm{~h}$ and analyzed further. Cells treated by $\mathrm{Hg}$ caused a significant cell viability reduction, membrane damage, glutathione reduction, DNA fragmentation, ROS generation, with suppressed expressions of akt, mTOR, ERK1, Nrf2 and HO1; and elevated apoptotic expressions of p53, Bax, cytochrome c and active caspase 3. However, BHT and $\mathrm{Hg}^{2+}$ co-exposure showed prevention against $\mathrm{Hg}^{2+}$-toxicity by improving GSH content and inhibiting ROS generation and oxidative stress mediated damages. Additionally, BHT co-treatment inverted the pro-apoptotic proteins by augmenting pro-survival regulatory proteins akt, mTOR, ERK1, Nrf2 and HO1. These findings proved that BHT inhibits $\mathrm{Hg}^{2+}$-toxicity, hindering $\mathrm{ROS}$ generation and intrinsic apoptosis, via enhancing glutathione and antioxidants; and suggested BHT implications as therapeutic.

Keywords: Oxidative stress; intrinsic apoptosis; Nrf2; heme oxygenege 1; ERK1; DNA fragmentation 


\section{Introduction}

Mercury $(\mathrm{Hg})$ is a universal environmental pollutant which causes a broad spectrum of fatal health effects. $\mathrm{Hg}$ is marked as the third in most dangerous and hazardous toxic materials, by the Agency for Toxic Substances and Disease Registry (ATSDR). Severe $\mathrm{Hg}$ pollution in the environment (atmosphere, lake water, lake sediments and catchment soils, soil feeding termites) of anthropogenically-disturbed sites (Zhang et al., 2019; Cheng et al., 2020; Diouf et al., 2019) and dreadful contaminations in food sources (fresh and marine fish, rice, clam) (Yoshino et al., 2020; Xu et al., 2020; S1kdokur et al., 2020) across the world have been reported. Three forms of Hg: elemental, inorganic and organic, can be exposed to human. $\mathrm{Hg}$ exposure typically occurs by inhalation or ingestion. Major sources of $\mathrm{Hg}$ are industrial emissions, fresh water and ocean fishes, and dental amalgam. For many years, inorganic $\mathrm{Hg}$ has been using in various medications, germicidal soaps, teething powders, and skin care products (Guzzi and Porta, 2008). Hg crosses blood brain barrier (BBB) and can cause irreversible effect on the central nervous system. All forms of $\mathrm{Hg}$ can cause neurological alteration, cognitive and motor dysfunction, memory loss, behavioral disorders, immune and kidney defects, and neurodevelopmental difficulties (Rahman et al., 2019). Moreover, studies have been shown to induce toxicity by $\mathrm{Hg}$ in vivo (Goering et al., 2000; Aragão et al., 2018) and in vitro (Shenker et al., 2002; Kaur et al., 2006; Teixeira et al., 2018; Hossain et al., 2021a). $\mathrm{Hg}$ was affirmed to induce oxidative stress and generate reactive oxygen species (ROS) in vivo and in vitro (Shenker et al., 2002; Aragão et al., 2018).

Butylated hydroxytoluene (BHT) is a widely recognized antioxidant, which was primarily used as a food additive, and also in other industries as industrial 
additive/preservative, personal care product, household product constituents, plastic/rubber components and medical/research uses. It is a hindered phenolic compound, also well-known as 2,6-di-tert-butyl-p-cresol or 2,6-di-tert-butyl-4methylphenol. It is not found in nature, but produced from p-cresol and isobutylene synthetically (Branen, 1975). It is categorized by the United States Food and Drug Administration (FDA) as "Generally Recognized As Safe" . Depending on the food fat content, a total of $0.02 \%$ of BHT is permitted (Babich, 1982). and is one of the most frequently consumed antioxidants in fats-containing-foods (Yehye et al., 2015). By donation of hydrogen to free-radicals, it can prevent lipid oxidation (Babich, 1982).

Several studies have been indicated BHT induced protective effects from metals (ferric ion (Ko and Godin, 1990), cadmium (Peters et al., 1995), chromium (Pourahmad and O'Brien, 2001), copper (Hosseini et al., 2014)) and other toxic compounds (copper oxide (Assadian et al., 2017), mancozeb (Tsang and Trombetta, 2007), melatonin (Gulcin et al., 2003)) induced toxicity in vivo and in vitro, though details mechanisms were not reported yet. Studies have indicated that the antioxidant property of BHT is the major cause of BHT-protection against reactive oxygen species (ROS) induced toxicity. Very few studies (Peters et al., 1995; Pourahmad and O'Brien, 2001; Hosseini et al., 2014) are present evaluating the protective effects of BHT against heavy metals induced cytotoxicity and the preventive role of BHT in the cells. The exact molecular mechanisms have not been elucidated yet. Moreover, because of the widespread usage of BHT, it is necessary to study about the safety of this antioxidant and critical evaluation of the safe limit of BHT. Most importantly, an effective solution to defend cells from $\mathrm{Hg}$ induced severe toxicity is very crucial and urgent. Therefore, the ameliorative effects of BHT against iHg induced toxicity and its molecular mechanisms 
have been studied in this research. Here, we hypothesized that BHT has a protective role on iHg-toxicity. The bio-molecular mechanisms involved in these protective effects were also investigated in the light of antioxidant property of BHT. In this research, PC12 cells were used as a model cell line for toxicity investigation (Hossain et al., 2018). To achieve our hypothesis, for the very first time, the protective effects of BHT were evaluated on $\mathrm{iHg}$ mediated toxicity in $\mathrm{PC} 12$ cells using various toxicity analysis methods.

\section{Methodology}

\subsection{Chemicals}

DMEM cell culture media was purchased from Sigma-Aldrich, USA. PC12 cells were bought from American Type Culture Collection (USA and Canada). BHT and $\mathrm{HgCl}_{2}$ were obtained from MP Biomedicals, LLC (France) and Wako Pure Chemical Corporation (Japan), respectively. Polyclonal antibodies against mammalian target of rapamycin (mTOR) (2972, Cell Signalling Technology), p-mTOR (Cosmo Bio Co.), Heme oxygenase 1 (GTX101147, GeneTex), extracellular signal-regulated kinases (ERK1) (610031, BD Transduction Laboratories), phosphorylated protein kinase B (akt) (9267, Cell Signalling Technology), akt (4691, Cell Signalling Technology), Nuclear factor erythroid 2-related factor 2 (Nrf2) (PM069, Medical and Biological Laboratories Co., Japan), p53 (2524, Cell Signalling Technology), Bax (2772, Cell Signalling Technology), Bcl-xL (612011, BD Transduction Laboratories), caspase 7 (610812, BD Transduction Laboratories), cleaved caspase-3 (NB100-56113SS, BioDynamics Laboratory Inc.), caspase 3 (GTX110543, GeneTEX), LC3 (83506, Cell Signaling Technology), $\beta$-actin (GeneTEX), were bought. Cytochrome c release Apoptosis Kit 
was bought from Calbiochem®. All chemicals used in this study were of analytical grade.

\subsection{Cell culture}

DMEM medium supplemented with $10 \%$ FBS were used to culture the PC12 cells. The cells were maintained at $37^{\circ} \mathrm{C}$ for $48 \mathrm{~h}$. The medium was exchanged with serum/serumfree DMEM with/ without different concentrations of $\mathrm{HgCl}_{2}\left(\mathrm{Hg}^{2+}\right)(0-5 \mu \mathrm{M})$ and butylated hydroxytoluene (BHT) $(0-1,000 \mu \mathrm{M})$, separately. The IC50 value for $\mathrm{HgCl}_{2}$ was analyzed. Upon analyzing IC50 value $(4.37 \mu \mathrm{M})$ of $\mathrm{Hg}$, the final concentration for $\mathrm{Hg}^{2+}$ was decided as $5 \mu \mathrm{M}$ for the co-exposure. $100 \mu \mathrm{M}$ of BHT was selected as the final concentration for the co-treatment, because till $100 \mu \mathrm{M}$ BHT did not show any toxic effect on the cells. The final combinations were decided as $5 \mu \mathrm{M}$ of $\mathrm{Hg}^{2+}$ and 100 $\mu \mathrm{M}$ of BHT for the co-treatment. Therefore, cells were treated with/without BHT (100 $\mu \mathrm{M})$, iHg $(5 \mu \mathrm{M})$, or BHT $(100 \mu \mathrm{M})$ and $\mathrm{iHg}(5 \mu \mathrm{M})$ together for $48 \mathrm{~h}$ and further tested for various cytotoxicity assessment analysis.

\subsection{Cell viability analysis}

The viability of the cells was dignified by trypan blue exclusion analysis as described by Kihara et al. (2012). Cells were incubated with/without BHT (100 $\mu \mathrm{M})$ and $\mathrm{iHg}(5$ $\mu \mathrm{M})$, or co-incubated with BHT $(100 \mu \mathrm{M})$ and $\mathrm{iHg}(5 \mu \mathrm{M})$ for $48 \mathrm{~h}$ in the DMEM supplemented with FBS (10\%). After the incubation, cells were harvested and washed using 1x PBS buffer. Cells were tainted with trypan blue dye. To measure the stained and non-stained cells, an automated cell counter (Bio-Rad, USA) was employed. These experiments were executed at least ten times to justify reliability.

\subsection{Lactate dehydrogenase ( $(\mathrm{DH})$ assay}


Lactate dehydrogenase activity analysis kit (Promega, USA) was used to assess the membrane integrity of the cells after $48 \mathrm{~h}$ of treatment with/without BHT $(100 \mu \mathrm{M}), \mathrm{iHg}$ $(5 \mu \mathrm{M})$ or BHT $(100 \mu \mathrm{M})$ and $\mathrm{iHg}(5 \mu \mathrm{M})$ together. After the $48 \mathrm{~h}$ of incubation of the cells with the various treatments, the culture medium of the cells was measured for LDH activity, as stated in Kihara et al. (2012). Reproducibility was verified by performing these analyses four times.

\subsection{Genomic DNA extraction}

Cells were incubated with/without BHT $(100 \mu \mathrm{M})$, iHg $(5 \mu \mathrm{M})$ or BHT $(100 \mu \mathrm{M})$ and $\mathrm{iHg}(5 \mu \mathrm{M})$ together for $48 \mathrm{~h}$, and then were harvested and washed with 1x PBS buffer. The technique explained by Kawakami et al. (2008) was used to extract DNA from the cells with High Pure PCR Template preparation kit (11796828001, Roche Diagnostics, Germany).

\subsection{Electrophoresis of genomic DNA}

The DNA was extracted as explained by Kawakami et al. (2008) and the intact genomic DNA of the cells was assayed by agarose gel electrophoresis assay. Isolated DNA of the cells treated or co-treated with/without BHT $(100 \mu \mathrm{M})$ and $\mathrm{iHg}(5 \mu \mathrm{M})$ were measured using 1.5\% agarose gel electrophoresis as defined by Hossain et al. (2018) and Kawakami et al. (2008). The fluorescence intensity of electrophoresed DNA was analyzed using 'Quantity one' software. The density of the intact DNA was later measured using ImageJ software. The reproducibility was ensured by performing this experiment at least four times.

\subsection{Reactive oxygen species (ROS) measurement}

Dihydroethidium (DHE) is a redox-sensitive fluorescent probe and oxidized by ROS. 
DHE was detected to investigate ROS generation using ROS detection cell-based assay kit (Cayman chemical, USA). Cells were treated with/without $\mathrm{Hg}^{2+}(5 \mu \mathrm{M}), \mathrm{BHT}(100$ $\mu \mathrm{M})$, and combination of BHT and $\mathrm{Hg}$ for $48 \mathrm{~h}$, then cells were harvested and incubated with ROS straining buffer. DHE fluorescent was measured according to manufacturer's instructions at $488 \mathrm{~nm}$ laser. BD FACSVerse ${ }^{\mathrm{TM}}$ flow cytometer (BD Biosciences) was used to analyze DHE fluorescence. The experiments were executed for three times to ensure reliability.

\subsection{Free sulfhydryl (SH) levels analysis}

Intracellular free SH or glutathione (GSH) levels assay was measured. PC12 cells were exposed or co-exposed with/without BHT $(100 \mu \mathrm{M})$ and $\mathrm{iHg}(5 \mu \mathrm{M})$ for $48 \mathrm{~h}$, and then were harvested and washed with 1x PBS buffer. The protein extraction and free SH level measurement were performed as stated by Rahman et al. (2017). The assay was conducted three times to verify reliability.

\subsection{Flow cytometry study}

Flow cytometry was used to assess the cell death process using Annxin V-FITC apoptosis detection kit (BioVision, USA). Cells were incubated or co-incubated with/without BHT $(100 \mu \mathrm{M})$ and $\mathrm{iHg}(5 \mu \mathrm{M})$ for $48 \mathrm{~h}$, and then flow cytometry was done as according to manufacturer's instruction. The experiments were performed three times for reliability.

\subsection{Western blot for protein expression determination}

Cells were treated with/without BHT $(100 \mu \mathrm{M})$ and $\mathrm{iHg}(5 \mu \mathrm{M})$, or treated with BHT $(100 \mu \mathrm{M})$ and $\mathrm{iHg}(5 \mu \mathrm{M})$ together for $48 \mathrm{~h}$. After incubation, cells were harvested and washed by 1x PBS. As described in Rahman et al. (2017) protein extraction from the 
cells and electrophoresis were done. Enhanced chemiluminescence was used to detect the protein bands and; those bands were evaluated by a ChemiDoc XRS (Bio-Rad, USA) and were quantified using 'Quantity one' software. The density of the protein band was later analyzed using ImageJ software. The reproducibility was ensured by performing these experiments at least four times.

\subsection{Statistics}

Data were presented as the mean \pm standard error of mean (SEM) of independent experiments (at least three). Analysis was performed using one-way ANOVA, followed by two-way ANOVA and unpaired Student's $t$-test for statistical analysis. Either $\mathrm{p}<0.05$ or $\mathrm{p}<0.01$ difference was reflected as significant statistically.

\section{Results}

\subsection{Assessment of cell viability}

(A)

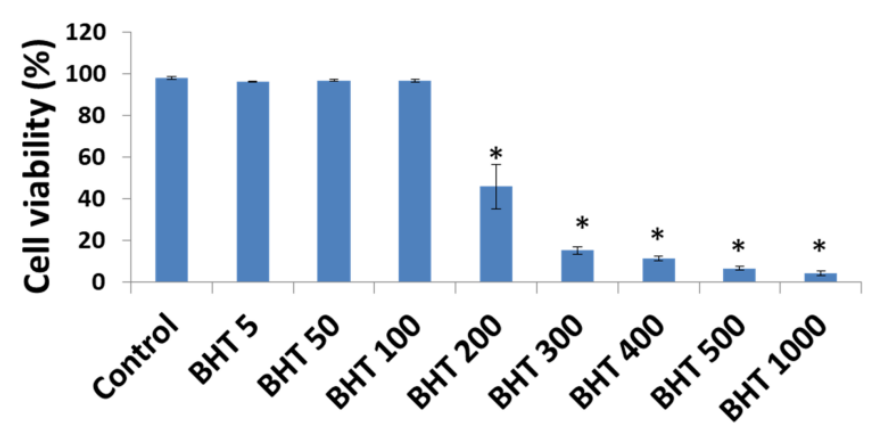

(B)
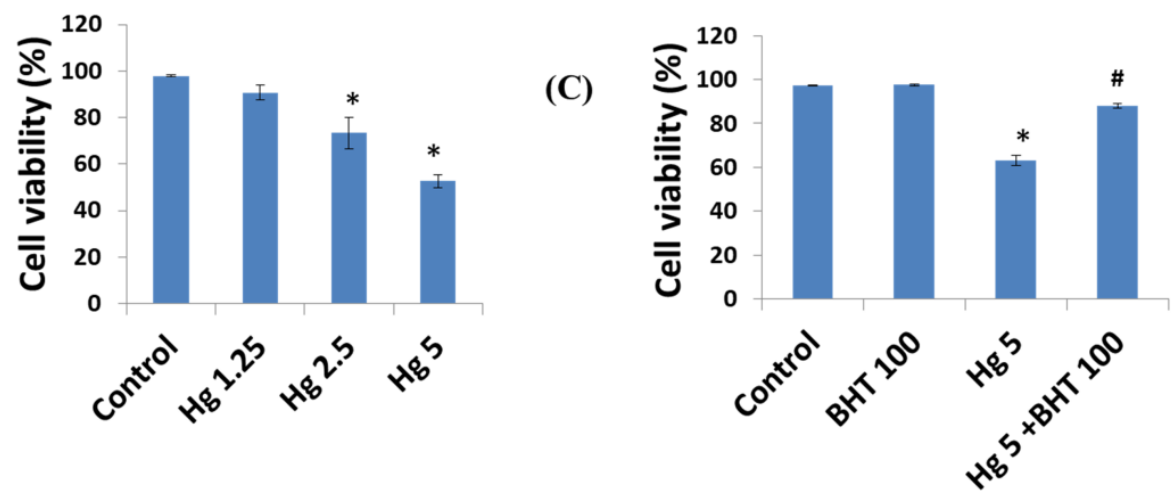

Fig. 1 (A) Cell viability of PC12 cells cultured in medium with $0-1,000 \mu \mathrm{M}$ of BHT, (B) 
Cell viability of PC12 cells cultured in medium with $0-5 \mu \mathrm{M}$ of $\mathrm{iHg}$, (C) Cell viability of PC12 cells co-exposed with BHT $(100 \mu \mathrm{M})$ and $\mathrm{iHg}(5 \mu \mathrm{M})$ for $48 \mathrm{~h}$ incubation. Error bars indicate mean $\pm \operatorname{SEM}(\mathrm{n}=$ at least 6$)$. * denotes $\mathrm{p}<0.05$, significantly difference from control group and \# denotes $\mathrm{p}<0.05$, significantly difference from only iHg-treated group.

To examine the BHT-effect on cells, cells were incubated with various concentrations $(0-1,000 \mu \mathrm{M})$. Fig. 1A shows the cell viability when incubated with $0-1,000 \mu \mathrm{M}$ of BHT. Up to $100 \mu \mathrm{M}$ of BHT concentrations the viability did not show any significant variance from the control cells (treated with no treatment). However, in over $100 \mu \mathrm{M}$ of BHT concentrations, the viability of the cells were drastically $(\mathrm{p}<0.01)$ reduced in opposition to the control group. This result indicated that upto $100 \mu \mathrm{M}$ concentration of BHT is not toxic or harmful to PC12 cells. For this reason $100 \mu \mathrm{M}$ of BHT was chosen for the combined treatment with iHg.

For selecting the $\mathrm{iHg}$ concentration for the combined treatment, PC12 cells were incubated with various concentrations of $\mathrm{iHg}$. Fig. 1B displays the viability of cells incubated with $0,1.25,2.5$ and $5 \mu \mathrm{M}$ of $\mathrm{iHg}$ concentrations. Cell groups treated with $1.25 \mu \mathrm{M}$ of $\mathrm{iHg}$ did not show any significant $(\mathrm{p}<0.01)$ difference in comparison with the control group, whereas cell groups treated with 2.5 and $5 \mu \mathrm{M}$ of $\mathrm{iHg}$, both displayed significant $(\mathrm{p}<0.01)$ cell viability loss in opposition to the control group, with IC50 value of 4.37 (approximately 5). For this reason, $5 \mu \mathrm{M}$ of $\mathrm{iHg}$ was chosen for the combined treatment with BHT.

To evaluate the ameliorative effect of BHT on iHg induced toxicity in cells, cells were incubated with/without BHT $(100 \mu \mathrm{M})$ and $\mathrm{iHg}(5 \mu \mathrm{M})$, or co-treated with BHT (100 $\mu \mathrm{M})$ and $\mathrm{iHg}(5 \mu \mathrm{M})$ for $48 \mathrm{~h}$; and cell viability assay was performed. Fig. $1 \mathrm{C}$ displayed the viability of cells treated or co-treated with/without BHT $(100 \mu \mathrm{M})$ and $\mathrm{iHg}(5 \mu \mathrm{M})$. 
The viability of the cells incubated with BHT $(100 \mu \mathrm{M})$ alone did not expressed any significant difference from the control group, but the cells incubated with only $\mathrm{iHg}$ (5 $\mu \mathrm{M})$ showed a significant $(\mathrm{p}<0.01)$ cell viability drop in opposition to the control. Interestingly, the cells treated with BHT $(100 \mu \mathrm{M})$ and $\mathrm{iHg}(5 \mu \mathrm{M})$ together displayed a significant $(\mathrm{p}<0.01)$ rise in cell viability when compare with the cells treated with only $\mathrm{iHg}(5 \mu \mathrm{M})$. These findings suggested that BHT has a protective regulatory effect on iHg-toxicity in PC12 cells.

\subsection{Cell-membrane integrity}

To assess the cytotoxicity of $\mathrm{iHg}$, cell-membrane damage was detected by trypan blue assay. Fig. 2A showed the pictures of cells treated or co-treated with/without BHT (100 $\mu \mathrm{M})$ and $\mathrm{iHg}(5 \mu \mathrm{M})$ for $48 \mathrm{~h}$ and then stained with trypan blue. Here, red colored cells are indicating the cell membrane damaged cells and green colored cells are indicating cell membrane intact cells. The cells incubated with only iHg, presented a significant increase of red colored (cell- membrane damaged or dead) cells, in opposition to control cells. However, the cells co-incubated with BHT $(100 \mu \mathrm{M})$ and $\mathrm{iHg}(5 \mu \mathrm{M})$, showed a significant decrease of red colored cells, when compared with the cells treated with only $\mathrm{iHg}(5 \mu \mathrm{M})$.

To double check the modulation of cell-membrane damage, another cytotoxicity assessment method LDH activity assay was conducted. Fig. 2B showed the LDH activity in the culture media incubated or co-incubated with/without BHT (100 $\mu \mathrm{M})$ and $\mathrm{iHg}(5 \mu \mathrm{M})$ for $48 \mathrm{~h}$. The activity of LDH in the cells incubated with only iHg (5 $\mu \mathrm{M})$, resulted in a significant rise $(\mathrm{p}<0.01)$ in opposition to that of the control group, which indicating a severe cell membrane damage. But the activity of $\mathrm{LDH}$ when co-treated with BHT $(100 \mu \mathrm{M})$ and $\mathrm{iHg}(5 \mu \mathrm{M})$, showed a significant $(\mathrm{p}<0.05)$ drop in opposition 
to the cells incubated with $\mathrm{iHg}(5 \mu \mathrm{M})$ alone; which indicating improvement in the cellmembrane. These findings together with cell viability assay evidenced that BHT protects cells from $\mathrm{iHg}$ induced cytotoxicity and membrane damage.

(A)

Live cell

0 Cell-membrane damaged cell

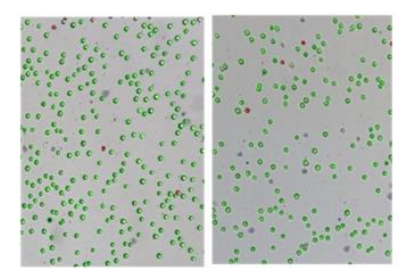

Control

(B)

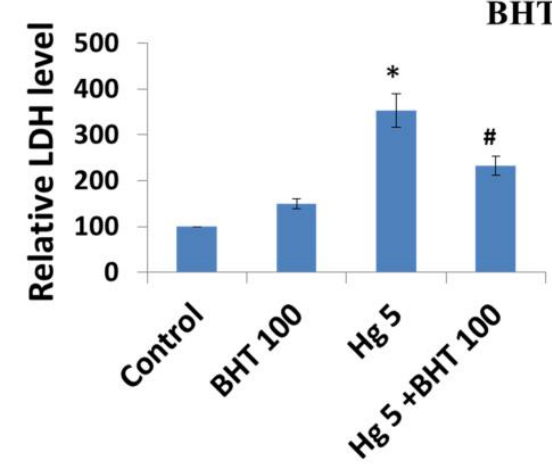

(C)

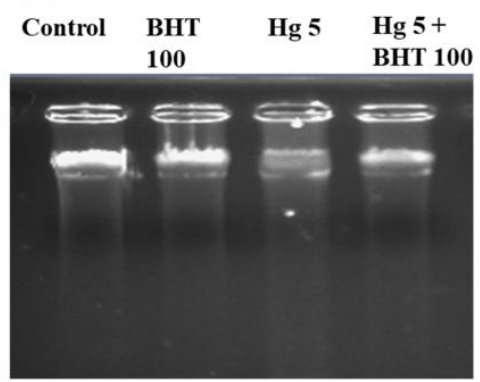

(D)

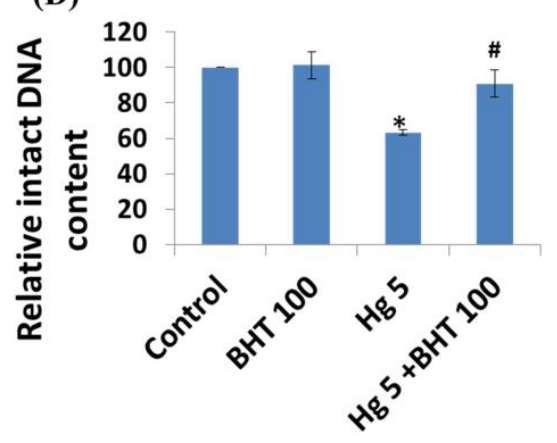

Fig. 2 (A) Detection of cell wall damage using trypan blue staining when cells were treated with/without BHT $(100 \mu \mathrm{M})$, iHg $(5 \mu \mathrm{M})$, or BHT $(100 \mu \mathrm{M})$ and $\mathrm{iHg}(5 \mu \mathrm{M})$ together for $48 \mathrm{~h}$. (B) LDH levels in the cultured medium for cells treated with/without BHT $(100 \mu \mathrm{M}), \mathrm{iHg}(5 \mu \mathrm{M})$, or BHT $(100 \mu \mathrm{M})$ and iHg $(5 \mu \mathrm{M})$ together for $48 \mathrm{~h}$. (C) Agarose gel electrophoresis of DNA isolated from PC12 cells treated with/without BHT $(100 \mu \mathrm{M}), \mathrm{iHg}(5 \mu \mathrm{M})$, or BHT $(100 \mu \mathrm{M})$ and $\mathrm{iHg}(5 \mu \mathrm{M})$ together for $48 \mathrm{~h}$ and (D) Intensity of electrophoresed band obtained from DNA of the cells. Error bars indicate mean \pm SEM (for $A$ and $B, n=5$; whereas for $C$ and $D, n=4$ ). * denotes $p<0.05$, significantly difference from control group and \# denotes $\mathrm{p}<0.05$, significantly difference from only iHg-treated group.

\subsection{DNA fragmentation}

Genomic DNA extraction and agarose gel electrophoresis experiment was implemented 
to evaluate the protective effect of BHT on $\mathrm{iHg}$ influenced cytotoxicity. Fig. 2C showed the image of electrophoresed extracted DNA of the cells incubated or co- incubated with/without BHT $(100 \mu \mathrm{M})$ and $\mathrm{iHg}(5 \mu \mathrm{M})$; and Fig. 2D showed the quantification of the intact DNA intensity. The amount of relative intact DNA was significantly $(p<0.05)$ reduced in the cells incubated with only $\mathrm{iHg}(5 \mu \mathrm{M})$ comparing to those control cells. On the other hand, the cells co-treated with BHT $(100 \mu \mathrm{M})$ and $\mathrm{iHg}(5 \mu \mathrm{M})$ together, revealed a significant $(\mathrm{p}<0.05)$ increase in the relative intact DNA level in opposition to the cells incubated with only $\mathrm{iHg}$. These findings suggested that BHT co-treatment with $\mathrm{iHg}$, improves the amount of intact DNA and inhibited $\mathrm{iHg}$ encouraged DNAfragmentation in cells.

\subsection{ROS generation}

Dihydroethidium (hydroethidine or DHE) was investigated to measure ROS generation Fig. 3A showed that relative DHE fluorescence or ROS amount in the cells treated with $\mathrm{iHg}(5 \mu \mathrm{M})$ was significantly $(\mathrm{p}<0.05)$ increased compared to the control group. On the other hand, the relative DHE fluorescent (ROS amount) was significantly $(p<0.05)$ decreased in cells co-treated with BHT $(100 \mu \mathrm{M})$ and $\mathrm{iHg}(5 \mu \mathrm{M})$, when compared with the group treated with only $\mathrm{iHg}(5 \mu \mathrm{M})$. These findings indicated that $\mathrm{iHg}$ induced cytotoxicity in PC12 cells via ROS generation and BHT co-treatment reduced $\mathrm{iHg}$ induced ROS formation. 
(A)

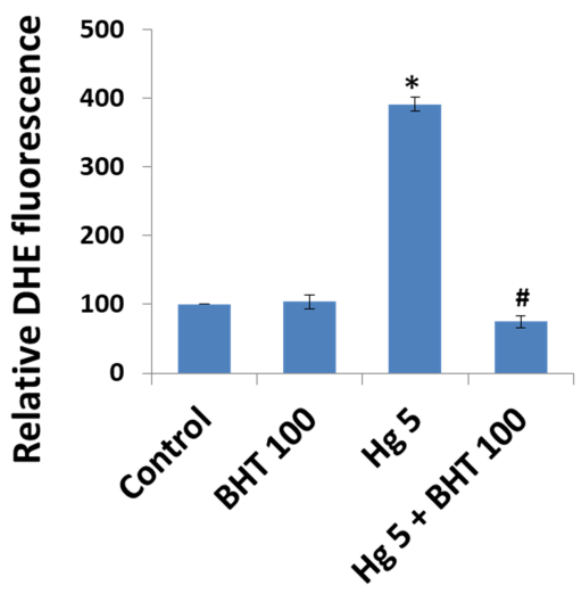

(B)

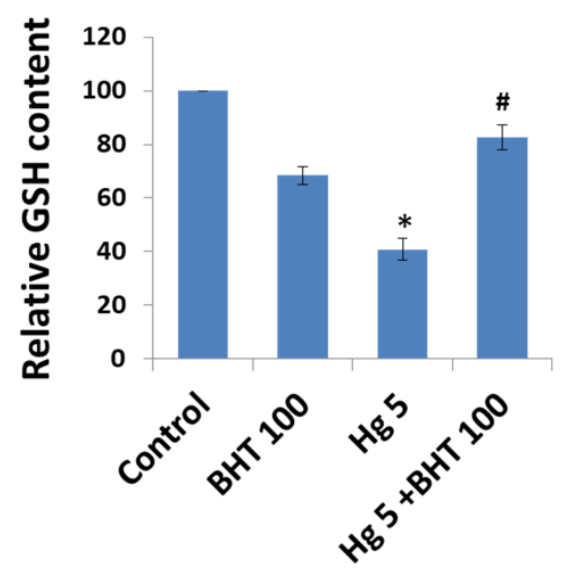

Fig. 3 (A) Relative geometric mean of DHE fluorescence and (B) GSH content of the cells treated with/without $\mathrm{Se}(5 \mu \mathrm{M}), \mathrm{iHg}(5 \mu \mathrm{M})$ or Se and $\mathrm{iHg}(5 \mu \mathrm{M}+5 \mu \mathrm{M})$ together. Error bars are mean $\pm \operatorname{SEM}(n=3)$. ${ }^{*}$ denotes $\mathrm{p}<0.05$, significantly difference from control group and \# denotes $\mathrm{p}<0.05$, significantly difference from only $\mathrm{Hg}$-treated group

\subsection{GSH levels}

Free $\mathrm{SH}$ group or glutathione level in the cells is a vital element for antioxidant defense mechanisms. Reduced GSH is altered to its oxidized form (GSSG) for defending the cells from ROS influenced oxidative stress. To assess the antioxidant defense state of the cells and the contribution of ROS mediated stress in iHg-treated cells, intracellular GSH level was evaluated. Fig. 3B showed the GSH level in cells incubated or coincubated with/without BHT $(100 \mu \mathrm{M})$ and $\mathrm{iHg}(5 \mu \mathrm{M})$. The GSH level in the cells incubated with only $\mathrm{iHg}(5 \mu \mathrm{M})$ was significantly $(\mathrm{p}<0.01)$ dropped in opposition to the control cells, indicating significant upsurge in ROS amount in the cells. Again, while compared with the cells treated with only $\mathrm{iHg}(5 \mu \mathrm{M})$, the GSH level of the cells cotreated with BHT $(100 \mu \mathrm{M})$ and $\mathrm{iHg}(5 \mu \mathrm{M})$ revealed a significant $(\mathrm{p}<0.01)$ uplift, indicating significant decrease in ROS amount in the cells. These findings suggested 
that $\mathrm{iHg}$ persuades ROS arbitrated oxidative stress and BHT protects the cells from ROS mediated oxidative stress and cell death by improving the GSH content of the cells.

\subsection{Apoptosis analysis}

To know about the cell death mechanisms flow cytometry analysis was employed. The cells exposed to only iHg $(5 \mu \mathrm{M})$, presented a significant growth $(\mathrm{p}<0.05)$ in apoptotic cells in opposition to the cells treated with no treatment (Fig. 4). Again, the cells cotreated with BHT $(100 \mu \mathrm{M})$ and $\mathrm{iHg}(5 \mu \mathrm{M})$, disclosed a significant decrease in apoptotic cells in opposition to the cells treated with only $\mathrm{iHg}(5 \mu \mathrm{M})$. These findings suggested that $\mathrm{BHT}$ provides protection from $\mathrm{iHg}$ mediated toxicity and inhibited apoptotic cell death.
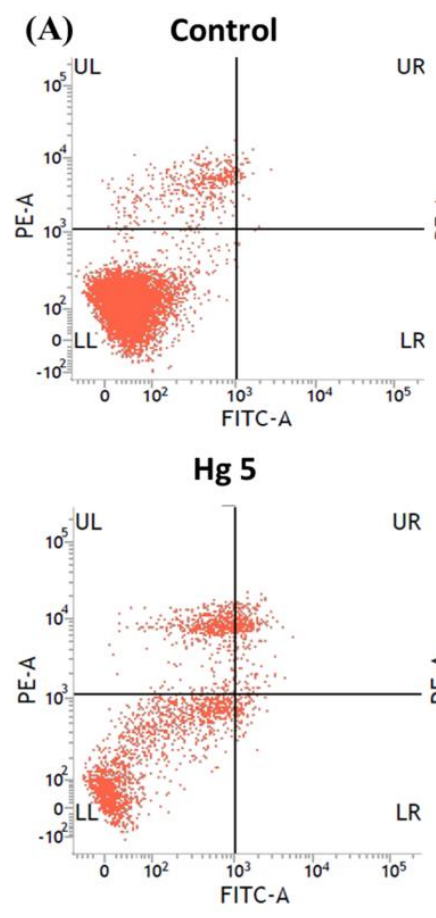

BHT 100

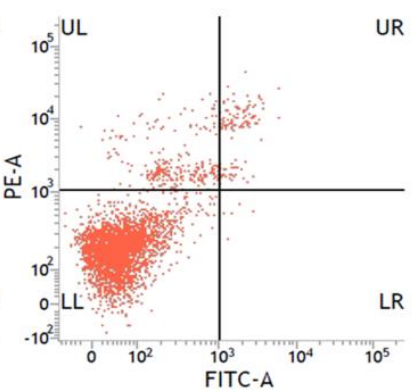

Hg $5+$ BHT 100

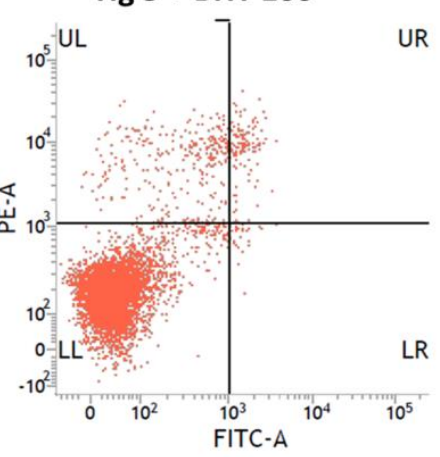

(B)

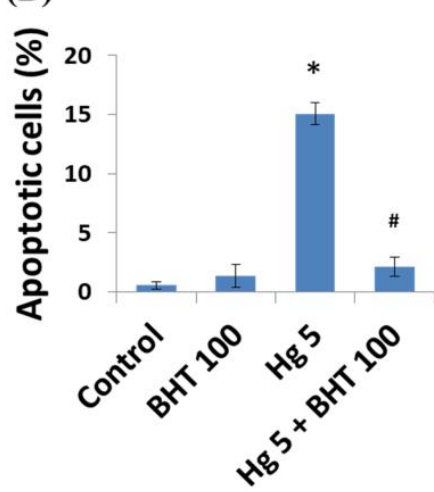

Fig. 4 (A) Flow cytometry analysis of cultured PC12 cells, strained with Annexin VFITC/PI after treatment with/without BHT $(100 \mu \mathrm{M})$, iHg $(5 \mu \mathrm{M})$, or BHT $(100 \mu \mathrm{M})$ and $\mathrm{iHg}(5 \mu \mathrm{M})$ together for $48 \mathrm{~h}$; and apoptotic cells $(\mathrm{B})$. Error bars are mean $\pm \mathrm{SEM}$ 
$(\mathrm{n}=3)$. * denotes $\mathrm{p}<0.05$, significantly difference from control group and \# denotes $\mathrm{p}<$ 0.05 , significantly difference from only $\mathrm{iHg}$-treated group.

\subsection{Expression of proteins}

The molecular mechanisms involved in BHT mediated protection and $\mathrm{iHg}$ induced toxicity in cells were investigated using western blotting analysis. The protein samples were extracted from the cells treated or co-treated with/without BHT $(100 \mu \mathrm{M})$ and $\mathrm{iHg}$ $(5 \mu \mathrm{M})$ and western blotting was performed. The protein expressions of p-akt, akt, pmTOR, mTOR, ERK1, Nrf2, HO1, p53, Bax, Bcl-xL, caspase 7, cleaved caspase-3, cytochrome c, caspase 3, LC3 and $\beta$-Actin were shown in Figs. 5 and 6.
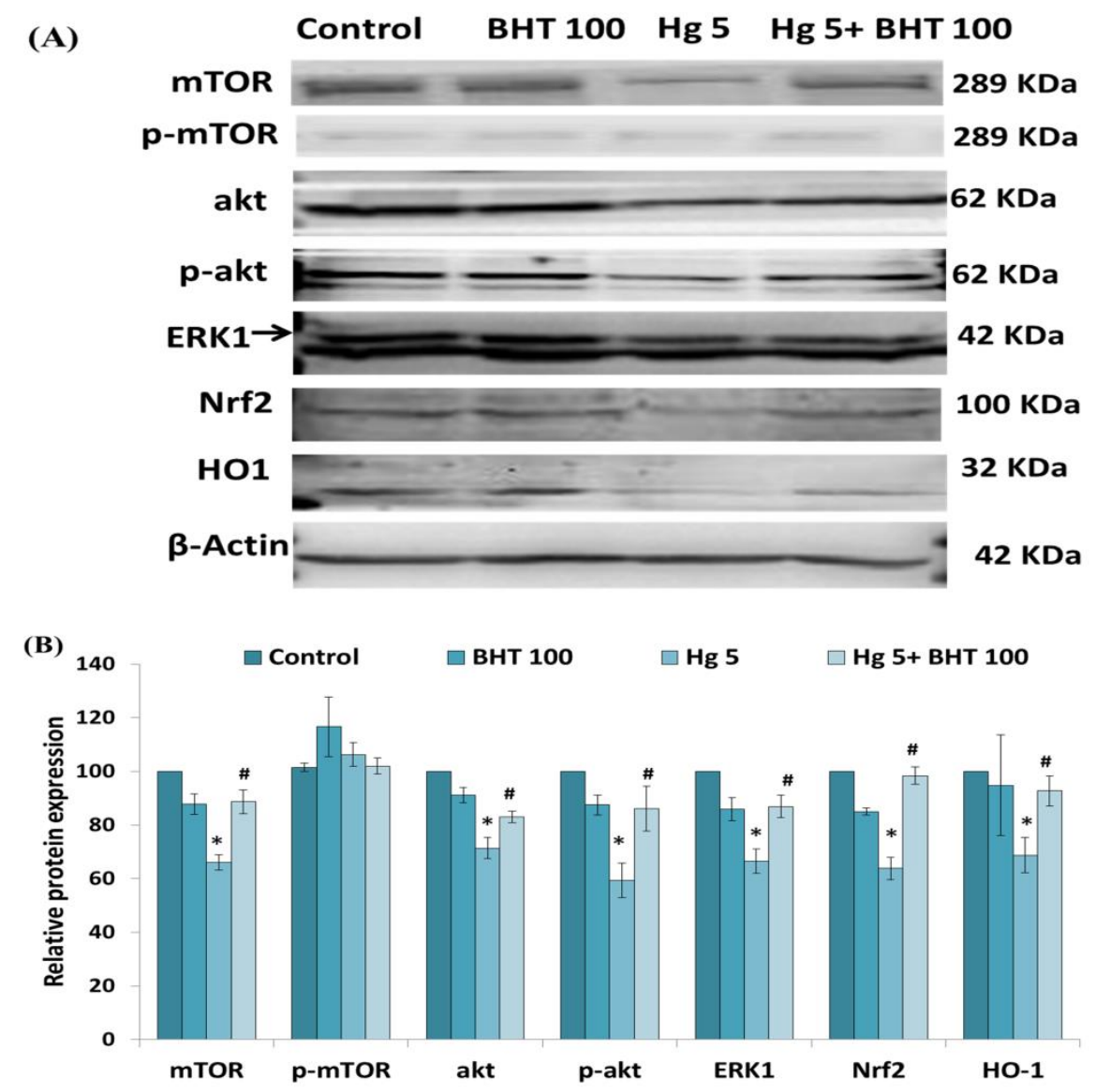

Fig. 5 (A) Protein expressions and (B) quantification of mTOR, p-mTOR, akt, p-akt, ERK1, Nrf2, HO1 and $\beta$-actin in the cultured cells treated with/without BHT (100 $\mu \mathrm{M})$, $\mathrm{iHg}(5 \mu \mathrm{M})$, or BHT $(100 \mu \mathrm{M})$ and $\mathrm{iHg}(5 \mu \mathrm{M})$ together for $48 \mathrm{~h}$. Error bars are mean \pm 
SEM $(n=3)$. * denotes $\mathrm{p}<0.05$, significantly difference from control group and \# denotes $\mathrm{p}<0.05$, significantly difference from only iHg-treated group.

The mTOR plays a principal regulatory role in cellular metabolism, growth, proliferation, differentiation and survival. mTOR and phosphorylated mTOR, both were investigated in this study (Fig. 5). The level of mTOR was significantly $(p<0.01)$ downregulated in cells treated with only $\mathrm{iHg}(5 \mu \mathrm{M})$ in opposition to that of the control group. Again, mTOR level was upregulated significantly $(\mathrm{p}<0.05)$ when co-incubated with BHT $(100 \mu \mathrm{M})$ and $\mathrm{iHg}(5 \mu \mathrm{M})$ in opposition to the cells incubated with only $\mathrm{iHg}$ $(5 \mu \mathrm{M})$. Though, the $\mathrm{p}$-mTOR level did not display any significant difference between the groups.

Akt regulates cellular metabolism, survival, cell cycle, and apoptosis by regulating many downstream proteins, for example, NFkB, Bcl-2 family proteins. To investigate the involvement of akt in this study, akt and phosphorylated akt were assessed (Fig. 5). Both p-akt and akt protein levels in the cells incubated with only $\mathrm{iHg}(5 \mu \mathrm{M})$, were significantly $(\mathrm{p}<0.01)$ reduced in opposition to the control cells proteins. Inversely, both proteins in the cells co-treated with BHT $(100 \mu \mathrm{M})$ and $\mathrm{iHg}(5 \mu \mathrm{M})$ were significantly increased compared to the only-iHg $(5 \mu \mathrm{M})$ treated cells.

ERK1/2 plays a crucial role in regulating cell proliferation, differentiation, cycle progression, metabolism, transcription and survival (Roskoski, 2012). The ERK1 level in the cells incubated with only $\mathrm{iHg}(5 \mu \mathrm{M})$, were significantly $(\mathrm{p}<0.01)$ reduced in opposition to the control cells proteins (Fig. 5). On the contrary, ERK1 in the cells coexposed to BHT $(100 \mu \mathrm{M})$ and $\mathrm{iHg}(5 \mu \mathrm{M})$ were significantly increased compared to the only-iHg $(5 \mu \mathrm{M})$ treated cells.

Nrf2 modulates the expression of antioxidant proteins e.g., glutathione reductage (GR) 
and heme oxygenase-1 (HO1) which defend against oxidative damage induced by inflammation and injury. To inquiry about the contribution of Nrf2-HO1 pathway, Nrf2 and HO1 protein levels were checked (Fig. 5). The level of Nrf2 was significantly $(\mathrm{p}<0.01)$ downregulated in cells exposed to only $\mathrm{iHg}(5 \mu \mathrm{M})$ significantly $(\mathrm{p}<0.01)$ reduced in opposition to the control cells; while the Nrf2 level was upregulated significantly $(\mathrm{p}<0.01)$ in cells co-exposed to BHT $(100 \mu \mathrm{M})$ and $\mathrm{iHg}(5 \mu \mathrm{M})$ in opposition to the cells treated with only $\mathrm{iHg}(5 \mu \mathrm{M})$. Again, while compared with the control group the HO1 level was significantly $(\mathrm{p}<0.01)$ reduced in the cells exposed to only iHg $(5 \mu \mathrm{M})$. And comparing with the only-iHg $(5 \mu \mathrm{M})$ treated group, HO1 level was significantly $(\mathrm{p}<0.05)$ increased in the group co-treated with BHT $(100 \mu \mathrm{M})$ and $\mathrm{iHg}(5 \mu \mathrm{M})$.
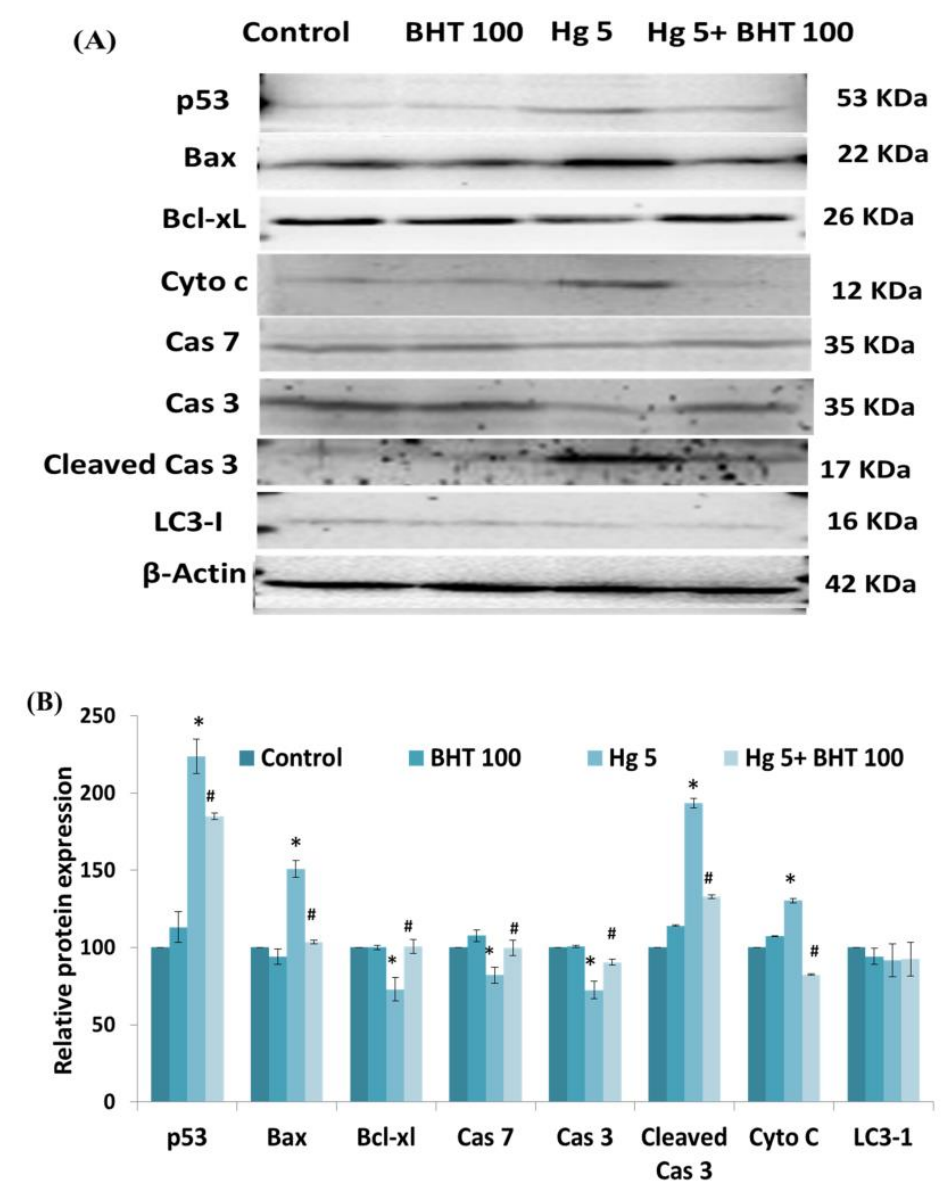
Fig. 6 (A) Protein expressions and (B) quantification of p53, Bax, Bcl-xL, cytochrome c, caspase 7, caspase 3, cleaved caspase 3, LC3-I and $\beta$-actin in the cultured cells treated with/without BHT $(100 \mu \mathrm{M}), \mathrm{iHg}(5 \mu \mathrm{M})$, or BHT $(100 \mu \mathrm{M})$ and $\mathrm{iHg}(5 \mu \mathrm{M})$ together for $48 \mathrm{~h}$. Error bars are mean $\pm \operatorname{SEM}(\mathrm{n}=3)$. * denotes $\mathrm{p}<0.05$, significantly difference from control group and \# denotes $\mathrm{p}<0.05$, significantly difference from only $\mathrm{iHg}$ treated group.

The p53 protein acts a fundamental part in responding to genomic abnormalities and DNA degradation; thus could cause seizure of cell cycle and apoptosis. The p53 protein level was abruptly $(\mathrm{p}<0.01)$ increased in cells incubated with only-iHg $(5 \mu \mathrm{M})$ in opposition to the control cells, whereas p53 level was significantly $(\mathrm{p}<0.05)$ decreased in cells co-incubated with BHT $(100 \mu \mathrm{M})$ and $\mathrm{iHg}(5 \mu \mathrm{M})$ together as compared with cells incubated with only-iHg (5 $\mu \mathrm{M})$ (Fig. 6).

The Bcl-2 family is well known regulatory proteins of programmed cell death apoptosis, which consists of pro-apoptotic or anti-apoptotic members that either promote or inhibit apoptosis and control apoptosis. These proteins regulate the permeability of mitochondrial outer layer and cytochrome c discharge into cytosol from mitochondria, which is a basic part of intrinsic apoptosis of the cells. In this research, with the cytochrome c level in the cytosol, pro-apoptotic Bcl-2 family protein Bax and antiapoptotic Bcl-2 family protein Bcl-xL have been studied (Fig. 6). The anti-apoptotic Bcl-xL level was significantly $(\mathrm{p}<0.05)$ downregulated in only-iHg $(5 \mu \mathrm{M})$-exposed cells in opposition to the control cells. Contrarily, Bcl-xL level was significantly $(\mathrm{p}<0.05)$ upregulated when cell treated with BHT $(100 \mu \mathrm{M})$ and $\mathrm{iHg}(5 \mu \mathrm{M})$ together as compared with the only-iHg $(5 \mu \mathrm{M})$-treated cells.

Moreover, the pro-apoptotic Bax level was significantly $(\mathrm{p}<0.01)$ upregulated in onlyiHg $(5 \mu \mathrm{M})$-treated cells while compared with that of the control cells. Inversely, Bax 
level was significantly $(\mathrm{p}<0.01)$ down regulated when cell treated with BHT $(100 \mu \mathrm{M})$ and $\mathrm{iHg}(5 \mu \mathrm{M})$ together as compared with the only-iHg (5 $\mu \mathrm{M})$-treated cells (Fig. 6). Similarly, cytochrome c level in the cytosol was significantly $(\mathrm{p}<0.01)$ upregulated in cells treated with only-iHg $(5 \mu \mathrm{M})$ while compared with that of the control cells; and indicating intrinsic apoptosis occurred in only-iHg $(5 \mu \mathrm{M})$ treated cells. Then again, cytochrome c level was significantly $(\mathrm{p}<0.01)$ downregulated when cell treated with BHT $(100 \mu \mathrm{M})$ and $\mathrm{iHg}(5 \mu \mathrm{M})$ together as compared with the only-iHg $(5 \mu \mathrm{M})$-treated cells; indicating inhibition of intrinsic apoptosis by BHT co-treatment.

Caspase 7 is an effector caspase family protein that executes apoptosis. Activation of caspase 7 is a sequential step of apoptosis induction. Caspase 7 protein level was significantly $(\mathrm{p}<0.01)$ downregulated in cells exposed to only $\mathrm{iHg}(5 \mu \mathrm{M})$ in opposition to that of the control group; indicating caspase 7 activation in only-iHg $(5 \mu \mathrm{M})$-treated cells. Again, caspase 7 level was upregulated significantly $(\mathrm{p}<0.05)$ when co-exposed to BHT $(100 \mu \mathrm{M})$ and $\mathrm{iHg}(5 \mu \mathrm{M})$ in opposition to the cells treated with only iHg $(5 \mu \mathrm{M})$; indicating inhibition of caspase 7 activation in co-treated group cells. Similarly, another vital caspase family protein caspase 3 and its activated form were also investigated in this study (Fig. 6). Caspase 3 protein level was significantly $(\mathrm{p}<0.01)$ downregulated in only-iHg $(5 \mu \mathrm{M})$-exposed cells in opposition to the control cells; indicating caspase 3 activation in only-iHg ( $5 \mu \mathrm{M})$-treated cells. Again, caspase 3 level was significantly $(\mathrm{p}<0.05)$ upregulated when cell treated with BHT $(100 \mu \mathrm{M})$ and $\mathrm{iHg}(5 \mu \mathrm{M})$ together as compared with the only-iHg $(5 \mu \mathrm{M})$-treated cells. The cleaved or activated caspase 3 level was significantly $(\mathrm{p}<0.01)$ increased in cell group treated with $\mathrm{iHg}(5 \mu \mathrm{M})$-only in opposition to the control group and confirmed apoptosis. Inversely, activated caspase 3 level was significantly $(\mathrm{p}<0.05)$ decreased in cell group co-exposed with BHT $(100 \mu \mathrm{M})$ 
and $\mathrm{iHg}(5 \mu \mathrm{M})$ compared to the group treated with only- $\mathrm{iHg}(5 \mu \mathrm{M})$ and confirmed blockage of apoptosis.

LC3 is a protein related to another programmed cell death autophagy, in which LC3-I is converted to LC3-II to conjugate autophagosomes. To investigate autophagy LC3 protein was assessed (Fig. 6), though only LC3-I was observed while LC3-II was absent indicating no involvement of autophagy. Fig. 7 depicts a graphic diagram of BHTinduced protection on $\mathrm{iHg}$ mediated toxicity in PC12 cells.

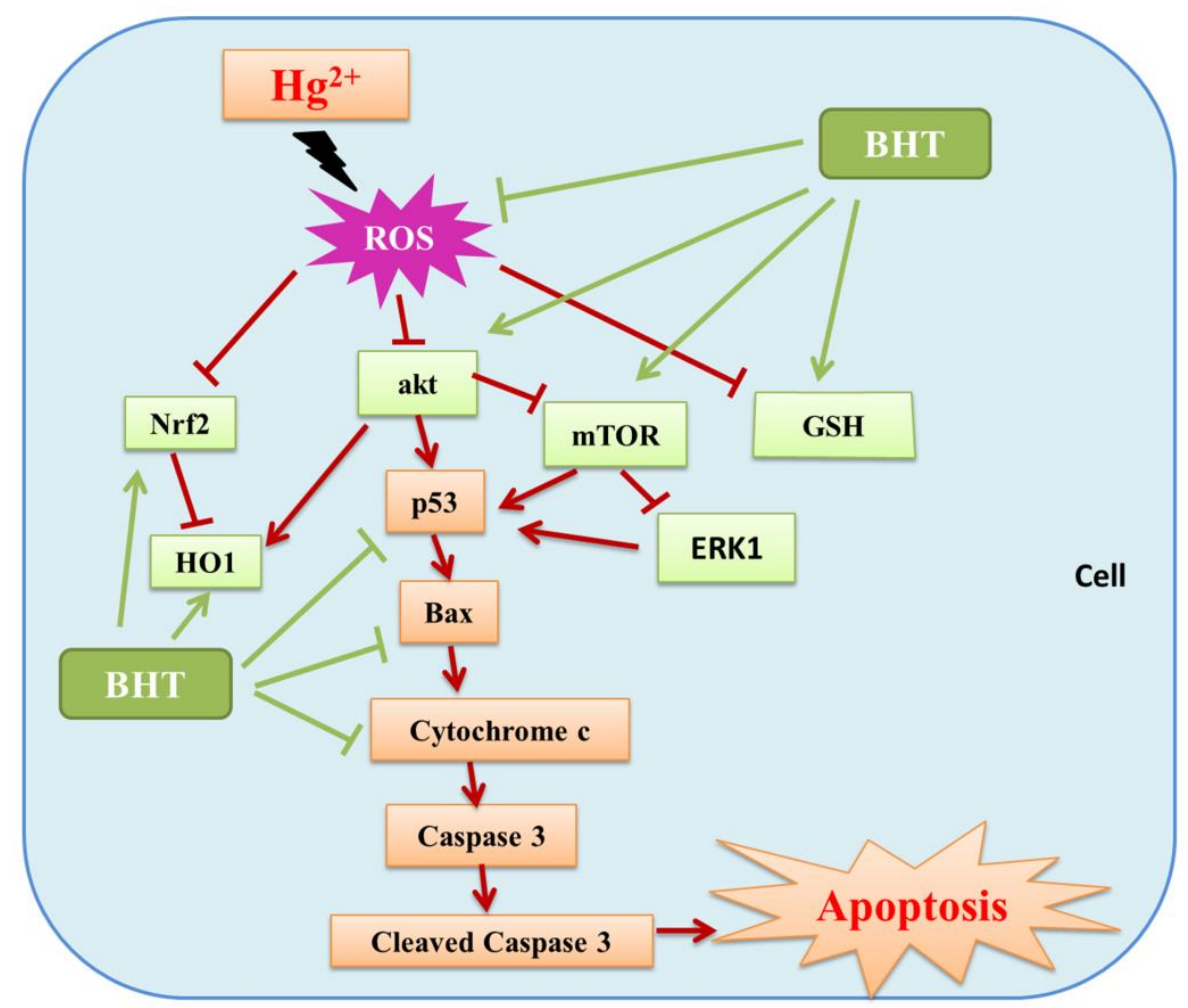

Fig. 7 Schematic diagram of BHT-protection on iHg-induced cytotoxicity in PC12 cells.

\section{Discussion}

There are approximately six thousand scientific articles discussing exclusively on BHT and its derivatives-induced antioxidant activities. BHA is a mixture of $15 \%$ 2-tert-butyl- 
4-hydroxyanisole (II) and 85\% 3-tertbutyl-4-hydroxyanisole (III) (Francois et al., 2012). Recently, BHT is comprehensively applied in the food industry, especially in low-fat foods, packaging materials and fish products (Yehye et al., 2015). After accumulation from food, BHT is primarily metabolized in liver and a small amount metabolized in lungs; and finally excreted via urine (Babich, 1982). The antioxidant property of BHT has been studied by various researchers (Lambert et al., 1996; Dawidowicz and Olszowy, 2011) indicating BHT as an inhibitor of free radical-chain reactions (Yehye et al., 2015). Numerous studies have been published on other antioxidants, where BHT has been used as an antioxidant standard (Dawidowicz and Olszowy, 2010; Sánchez-Vioque et al., 2012). In this study the antioxidant properties of BHT have been studied against a heavy metal induced toxicity (e.g., inorganic $\mathrm{Hg}$ mediated cytotoxicity) in PC12 cells using several cytotoxicity assessment assays.

$\mathrm{Hg}$ is an extremely toxic substance to human health, which has been evidenced to be hazardous even at a low concentration. In our research, relatively higher concentration was used to induce toxicity in PC12 cells. Cells exposed to iHg concentration $(5 \mu \mathrm{M})$ showed a significant cell viability reduction (Fig. 1), compromised cell membrane integrity (Fig. 2), genomic DNA fragmentation (Fig. 2), reduced glutathione amount decrease (Fig. 3) and ROS generation (Fig. 3). Similar results were also found by previous researches. Kim et al. (2003) reported similar iHg induced cell viability loss, cell membrane damage (LDH release) and blocked DNA proliferation in murine $\mathrm{T}$ and B lymphoma cells. Lee et al. (2001) described iHg influenced cell viability loss, ROS generation and GSH content drop in glioma cells. In our previous research (Hossain et al., 2020; 2021a; 2021b), iHg has been proved to be apoptogenic to PC12 cells. Similarly, our present research has appeared to encourage apoptosis in PC12 cells via 
mitochondrial pathway (Figs. 3 and 5). iHg caused downregulating p-akt, akt, mTOR, ERK1, Nrf2, HO1, Bcl-xL, inactivate caspase 7 and inactivated caspase 3 expressions; whereas resulted in upregulating protein expressions of p53, Bax, cleaved caspase 3 and cytochrome c (Figs. 4 and 5) synergistically, demonstrating oxidative stress and ROS generation. Kim et al. (2003) reported similar iHg induced apoptosis in lymphoma cells. Teixeira et al. (2018) showed $\mathrm{iHg}$ mediated oxidative stress and apoptosis in motor cortex. We demonstrated here that $\mathrm{iHg}(5 \mu \mathrm{M})$ induces cytotoxicity and cell death in PC12 cells via compromising cellular antioxidant defense associated with oxidative stress.

To protect cells from heavy metal induced toxicity, various antioxidants (selenium, dihydrolipoic acid, zinc) have been used for limiting ROS generation and oxidative stress (Hossain et al., 2018; 2020; 2021a; 2021b; Rahman et al., 2017). Several line of researches have been shown the possibility of BHT-protection upon heavy metals and other toxicants-induced toxicity (Hosseini et al., 2014; Al-Malki, 2010; Assadian et al., 2017; Tsang and Trombetta, 2007; Gulcin et al., 2003). In our research, BHT (100 $\mu \mathrm{M})$ co-treatment with $\mathrm{iHg}(5 \mu \mathrm{M})$ showed significant improvement in cell viability, genomic DNA and cell membrane integrity (LDH level decrease) Similarly, Tsang and Trombetta (2007) reported BHT-improved cell viability from mancozeb-induced cytotoxicity in rat hippocampal astrocytes. Lison et al. (1995) demonstrated in a macrophage culture model, BHT decreased the LDH release caused by the cytotoxicity of hard metal particles (cobalt metal and carbide particles). Again, Pourahmad and O'Brien (2001) showed that BHT prevented dichromate induced lipid peroxidation in isolated rat hepatocytes. Assadian et al. (2017) showed BHT mediated protection from lipid peroxidation caused by copper oxide nanoparticles influenced toxicity on human 
blood lymphocytes. Ko and Godin (1990) demonstrated that BHT inhibited the ferric ion-influenced peroxidation of erythrocyte membrane lipids. In our study, reduced glutathione content was improved by BHT $(100 \mu \mathrm{M})$ co-treatment with $\mathrm{iHg}(5 \mu \mathrm{M})$ indicating ROS formation. Similar to our results, Assadian et al. (2017) showed BHT induced glutathione content increase in human blood lymphocytes after copper oxide nanoparticles-treatment. Pourahmad and O'Brien (2001) showed that BHT prevented dichromate induced reactive oxygen species (ROS) formation in isolated rat hepatocytes. It was assumed that the mechanism of BHT associated antioxidant properties consist of the quenching of ROS and lipid soluble radicals (Yehye et al. 2015).

Antioxidant activity is extensively utilized as factor to illustrate substances with the property of neutralizing free radicals, by which the substance is able to protect a biological system from harmful oxidation. Scavenging property of BHT has been scrutinized critically (Yehye et al. 2015; Gulcin et al., 2003) and considered the major cause of antioxidant activity. Upon BHT co-treatment GSH upregulation and reduction in ROS amount in our results indicated that, BHT amelioration in presence of $\mathrm{iHg}$ toxicity is mediated through ROS scavenging/neutralization.

In our study, the proteins responsible for cellular metabolism, cell survival and cell cycle, akt, p-akt, mTOR, ERK1 were rejuvenated by BHT exposure against iHg induced toxicity. Here, BHT was able to upregulated the anti-apoptotic and pro-survival proteins mTOR, akt and ERK1. These upstream regulator proteins contributed as the initiator proteins of survival in PC12 cells and protected from iHg-induced cell death. One of the major cell survival pathways, Nrf2-HO1 is also potential to contribute in BHT induced protection, as p-akt, Nrf2 and HO1 were upregulated upon BHT co-exposure with iHg. Nrf2 as a transcription factor sensing oxidative stress, regulated the expression 
of antioxidant $\mathrm{HO} 1$ protein that protect against oxidative damages triggered by injury and inflammation in the cell. Similar Nrf2 and HO1 protein upregulation was also found in another antioxidant dihydrolipoic acid protection against $\mathrm{iHg}$-induced toxicity (Hossain et al., 2020). In this study, as upstream regulator proteins (akt, p-akt, mTOR, ERK1, Nrf2, HO1) were recovered by BHT exposure, downstream effector proapoptotic proteins (p53, Bax, caspase 7, cytochrome c and caspase 3) were inhibited, preserving mitochondrial membrane potentiality and modulated apoptosis caused by iHg in PC12 cells. Hosseini et al. (2014) reported BHT mediated protection from lipid peroxidation caused by copper toxicity on isolated liver mitochondria, describing mitochondrial membrane potential loss. Again, Assadian et al. (2017) showed BHT improved mitochondrial membrane potential in human blood lymphocytes after copper oxide nanoparticles-treatment.

In summary, consistent with previous reports, our study elucidated that $\mathrm{iHg}$ induced cytotoxicity in PC12 cells via antioxidant defense disruption and oxidative damages, which resulted cell death in intrinsic/mitochondrial apoptosis pathway. Inversely, BHT co-treatment with $\mathrm{iHg}$ protected the cells from iHg-cytotoxicity by intensifying antioxidant defense molecules and preserving from oxidative stress. BHT augmented glutathione content to modify oxidative stress induced by $\mathrm{iHg}$, indicating preservation of oxidative homeostasis. BHT induced homeostasis led restoration of upstream survival regulating proteins (mTOR, akt, ERK1, Nrf2 and HO1) and limited proapoptotic proteins (p53, Bax, cytochrome c and caspase 3). The apoptosis inhibition by BHT upon iHg exposure suggested that, BHT may have ameliorative properties against heavy metal induced cytotoxicity. This is the first study directly enlightening the ameliorative effect of BHT against iHg-toxicity. BHT appeared to be a good antioxidant 
against $\mathrm{Hg}$ induced toxicity and cellular damages, which suggested a possible therapeutic agent against not only $\mathrm{Hg}$, but also other heavy metal-induced toxicity facilitated by oxidative stress.

\section{Conclusions}

Our results demonstrated that $\mathrm{iHg}$ is highly toxic to PC12 cells, whereas BHT can protect PC12 cells from iHg-induced toxicity and intrinsic apoptosis. The protection provided by $\mathrm{BHT}$ in iHg-mediated toxicity is briefly via its antioxidant properties. It was suggested that $\mathrm{BHT}$ amelioration in presence of $\mathrm{iHg}$ is mediated via inhibition of ROS generation, GSH stimulation and oxidative stress reduction. Simultaneously, aktmTOR upregulation contributed as initial protein response in BHT-protection against iHg-toxicity. Our research provided strong evidence of the involvement and contribution of Nrf2-HO1 pathway in BHT mediated amelioration. Further analysis is needed to investigate the chelation capability of BHT. The results obtained from our research can be beneficial for pharmaceuticals and pharmacological uses of BHT as a therapeutic agent against heavy metals and environmental toxic substances. This is the first study directly enlightening the ameliorative effect of BHT against $\mathrm{iHg}$-toxicity on cells. 


\section{References}

Al-Malki, A.L. 2010. Antioxidant properties of thymol and butylated hydroxytoluene in carbon tetrachloride-induced mice liver injury. J. King Abdulaziz Univ. Sci. 22, 239-248. https://doi.org/10.4197/Sci. 22-1.16

Aragão, W.A.B., Teixeira, F.B., Fagundes, N.C.F., Fernandes, R.M., et al., 2018. Hippocampal dysfunction provoked by mercury chloride exposure: evaluation of cognitive impairment, oxidative stress, tissue injury and nature of cell death. Oxid. Med. Cell. Longe. 7878050. https://doi.org/10.1155/2018/7878050

Assadian, E., Zarei, M.H., Gilani, A.G., Farshin, M., Degampanah, H., Pourahmad, J. 2017. Toxicity of copper oxide (CuO) nanoparticles on human blood lymphocytes. Biol Trace Elem Res 184(2), 350-357. https://doi.org/10.1007/s12011-017-1170-4

Babich, H. 1982. Butylated hydroxytoluene (BHT): a review. Environ. Res. 29, 1-29.

Branen, A.L. 1975. Toxicology and biochemistry of butylated hydroxyanisole and butylated hydroxytoluene. J. Am. Oil Chem’ Soc. 52, 59-63.

Cheng, Z., Tang, Y., Li, E., Wu, Q., Duan,L. 2020. Mercury accumulation in soil from atmospheric deposition in temperate steppe of Inner Mongolia, China. Environ. Pollut. $258,113692$.

Dawidowicz, A.L., Olszowy, M. 2010. Influence of some experimental variables and matrix components in the determination of antioxidant properties by $\beta$-carotene bleaching assay: experiments with BHT used as standard antioxidant. Eur. Food Res. Technol. 231, 835. https://doi.org/10.1007/s00217-010-1333-4 
Dawidowicz, A.L., Olszowy, M. 2011. Antioxidant properties of BHT estimated by ABTS assay in systems differing in $\mathrm{pH}$ or metal ion or water concentration. Eur. Food Res. Technol. 232, 837-842. https://doi.org/10.1007/s00217-011-1451-7

Diouf, M., Sillam-Dussès, D., Alphonse, V., Frechault, S., Mora, P. 2019. Mercury species in the nests and bodies of soil-feeding termites, Silvestritermes spp. (Termitidae, Syntermitinae), in French Guiana. Environ. Pollut. 254, 113064.

Goering, P.L., Fisher, B.R., Noren, B.T., Papaconstantinou, A., Rojko, J.L., Marler, R.J. 2000. Mercury induces regional and cell-specific stress, protein expression in rat kidney. Toxicol. Sci. 53, 447-457.

Gulcin, I., Buyukokuroglu, M.E., Kufrevioglu, O.I., 2003. Metal chelating and hydrogen peroxide scavenging effects of melatonin. J. Pineal. Res. 34, 278-281.

Guzzi, G.P., Porta, C.A.M.L. 2008. Molecular mechanisms triggered by mercury. Toxicology 244, 1-12

Hossain, K.F.B., Rahman, M.M, Sikder, M.T., Saito, T., Hosokawa, T., Kurasaki, M., 2018. Inhibitory effects of selenium on cadmium-induced cytotoxicity in PC12 cells via regulating oxidative stress and apoptosis. Food Chem. Toxicol. 114, 180189. \%\%...\% ...https://doi.org/10.1016/j.fct.2018.02.034

Hossain, K.F.B., Rahman, M.M., Sikder, M.T., Hosokawa, T., Saito, T., Kurasaaki, M. 2020a. Regulatory effects of dihydrolipoic acid against inorganic mercury-mediated cytotoxicity and intrinsic apoptosis in PC12 cells. Ecotoxicol. Environ. Safe. 192, 110238. https://doi.org/10.1016/j.ecoenv.2020.110238

Hossain, K.F.B., Rahman, M.M., Sikder, M.T., Hosokawa, T., Saito, T., Kurasaaki, M. 
2021a. Selenium modulates inorganic mercury induced cytotoxicity and intrinsic apoptosis in PC12 cells. Ecotoxicol. Environ. Saf. 207, 111262. https://doi.org/10.1016/j.ecoenv.2020.111262

Hossain, K.F.B., Hosokawa, T., Saito, T., Kurasaaki, M. 2021b. Zinc-pretreatment triggers glutathione and Nrf2-mediated protection against inorganic mercury-induced cytotoxicity and intrinsic apoptosis in PC12 cells. Ecotoxicol. Environ. Saf. 207, 111320. https://doi.org/10.1016/j.ecoenv.2020.111320

Hosseini, M., Shaki, F., Ghazi-Khansari, M., Pourahmad, J. 2014. Toxicity of copper on isolated liver mitochondria: impairment at complexes I, II, and IV leads to increased ROS production. Cell. Biochem. Biophys. 70, 367-381.

Kaur, P., Aschner, M., Syversen, T. 2006. Glutathione modulation influences methyl mercury induced neurotoxicity in primary cell cultures of neurons and astrocytes. Neuro. Toxicol. 27, 492-500.

Kawakami, M., Inagawa, R., Hosokawa, T., Saito, T., Kurasaki, M., 2008. Mechanism of apoptosis induced by copper in PC12 cells. Food Chem. Toxicol. 46, 2157-2164.

Kihara, Y., Yustiawati, Tanaka, M., Gumiri, S., Ardianor, Hosokawa, T., Tanaka, S., Saito, T., Kurasaki, M., 2012. Mechanism of the toxicity induced by natural humic acid on human vascular endothelial cells. Environ. Toxicol. 29, 916-925. https://doi.org/10.1002/tox.21819.

Kim, S.H., Sharma, R.P., 2003. Cytotoxicity of inorganic mercury in murine T and B lymphoma cell lines: involvement of reactive oxygen species, $\mathrm{Ca}^{2+}$ homeostasis, and cytokine gene expression. Toxicol. In Vitro 17, 385-395. 
Ko, K.M., Godin., D.V., 1990. Ferric ion-induced lipid peroxidation in erythrocyte membranes: effects of phytic acid and butylated hydroxytoluene. Mol. Cell Biochem. 95, 125-131.

Lambert, C.R., Black, H.S., Truscott, T.G., 1996. Reactivity of butylated hydroxytoluene. Free Radic. Biol. Med. 21, 395-400

Lee, Y.W., Ha, M.S., Kim, Y.K. 2001. Role of reactive oxygen species and glutathione in inorganic mercury-induced injury in human glioma cells. Neurochem. Res. 26, 11871193.

Lison, D., Carbonnelle, P., Mollo, L., Lauwerys, R., Fubini, B. 1995. Physicochemical mechanism of the interaction between cobalt metal and carbide particles to generate toxic activated oxygen species. Chem. Res. Toxicol. 8, 600-606.

Peters, J.M., Duncanb, J.R., Wiley, L.M., Keen, C.L. 1995. Influence of antioxidants on cadmium toxicity of mouse preimplantation embryos in vitro. Toxicology 99, 11-18.

Pourahmad, J., O'Brien, P.J., 2001. Biological reactive intermediates that mediate chromium (VI) toxicity. Biological Reactive Intermediates VI, Edited by Dansette et al. Kluwer Academic/Plenum Publishers.

Rahman, M.M., Hossain, K.F.B., Banik, S., Sikder, M.T., Akter, M., Bondad, S.E.C., Rahaman, M.S., Hosokawa, T., Saito, T., Kurasaki M. 2019. Selenium and zinc protections against metal-(loids)-induced toxicity and disease manifestations: a review. Ecotoxicol. Environ. Safe. 168, 146-163. https://doi.org/10.1016/j.ecoenv.2018.10.054.

Rahman, M.M., Ukiana, J., Lopez, R.U., Sikder, M.T., Saito, T., Kurasaki, M., 2017. Cytotoxic effects of cadmium and zinc co-exposure in PC12 cells and the underlying 
mechanism. Chem. Biol. Interact. 269, 41-49.

Roskoski, R.Jr., 2012. ERK1/2 MAP kinases: structure, function, and regulation. Pharmacol. Res. 66, 105-143. https://doi.org/10.1016/j.phrs.2012.04.005.

Sánchez-Vioque, R., Rodríguez-Conde, M.F., Reina-Urẽ na, J.V., Escolano-Tercero, M.A., Herraiz-Pẽ nalver, D., Santana-Méridas, O., 2012. In vitro antioxidant and metal chelating properties of corm, tepal and leaf from saffron (Crocus sativus L.) Ind. Crop Prod. 39, 149-153.

Shenker, B.J., Pankoshi, L., Zekavat, A., Shapiro, I.M. 2002. Mercury-Induced Apoptosis in Human Lymphocytes: caspase activation is linked to redox status. Antioxid. Redox Sign. 4, 379-389.

Sikdokur, E., Belivermiş, M., Sezer, N., Pekmez, M., Kılıç, O. 2020. Effects of microplastics and mercury on manila clam Ruditapes philippinarum: Feeding rate, immunomodulation, histopathology and oxidative stress. Environ. Pollut. 262, 114247.

Teixeira, F.B., Oliveira, A.C.A., Leão, L.K.R., Fagundes, N.C.F., Fernandes, R.M., et al., 2018. Exposure to inorganic mercury causes oxidative stress, cell death, and functional deficits in the motor cortex. Front. Mol. Neurosci. 11, 125. https://doi.org/10.3389/fnmol.2018.00125

Tsang, M.M, Trombetta, L.D. 2007. The protective role of chelators and antioxidants on mancozeb-induced toxicity in rat hippocampal astrocytes. Toxicol. Ind. Health 7, 459470

Xu, X., Han, J., Pang, J., Wang, X., Qiu, G. 2020. Methylmercury and inorganic mercury in Chinese commercial rice: Implications for overestimated human exposure 
and health risk. Environ. Pollut. 258, 113706.

Yehye W.A., Rahman, N.A., Ariffin, A., Hamid, S.B.A., Alhadi, A.A., Kadir, F.A., Yaeghoobi, M. 2015. Understanding the chemistry behind the antioxidant activities of butylated hydroxytoluene (BHT): a review. Eur. J. Med. Chem. 101, 295-312.

Yoshino, K., Mori, K., Kanaya, G., Kojima, S., Yamamoto, M. 2020. Food sources are more important than biomagnification on mercury bioaccumulation in marine fishes. Environ. Pollut. 262, 113982.

Zhang, H., Wang, Z., Wang, C., Zhang, X. 2019. Concentrations and gas-particle partitioning of atmospheric reactive mercury at an urban site in Beijing, China. Environ. Pollut. 249, 13-23. 